\title{
AMBROSIUS EN DIE MARIAVERERING
}

As 'n mens die sobere gegewens in die Heilige Skrif oor Maria in oënskou neem ${ }^{1}$ ) en bemerk hoe die Goddelik-geinspireerde Bybelskrywers haar - die geseënde onder die vroue ${ }^{2}$ ) op die agtergrond stel sodat Jesus Christus die allesbeheersende middelpunt kan wees, is dit onbegryplik waarom Maria, veral in die Roomse Kerk, so hoog gestel word dat Theodor Kaftan die bewering maak: „In der römischen Kirche ist die Christuskirche zu einer Marienkriche geworden."3)

Dieselfde verbasing gryp mens aan as jy die geskiedenis van die Kerk in die eerste eeue nagaan. Nêrens bemerk 'n mens die geringste spoor van 'n Mariaverering nie ${ }^{4}$ ). Dit was eers soos Duruy dit stel - „with the lapse of time" dat die ,historic person" 'n ,"sacred type" geword het. ${ }^{5}$ )

Dit lê nie op ons weg om die ontwikkeling van die Mariaverering in detail te skilder nie. Dit gaan om die ontwikkeling van die Marialeer by Ambrosius. Aan die ander kant kán ons Ambrosius se gedagtegang ook nie meer van die voorafgaande historiese ontwikkeling isoleer nie. Daarom is ' $n$ kursoriese oorsig van die Maria-ontwikkeling noodsaaklik.

Soos reeds vermeld beweeg die Mariagestalte aan die begin van die kerklike era op die agtergrond. ${ }^{6}$ ) Dit is eers in die middel van die tweede eeu dat ons ' $n$ ontwikkeling waarneem as Justinus 'n parallelisme tussen Eva en Maria trek, ${ }^{7)}$ en as Irenaeus die parallelisme verder deurtrek in die bewering dat Maria die ,advocata Evae" is. ${ }^{8}$ )

Die Mariabeskouing het ' $n$ verdere vernuwing ontvang deur die ,exaggerated reverence for the ascetic life and for celibacy"9). Hiervolgens het Maria ,the type and ideal- of virginity" geword. ${ }^{10)}$ Weliswaar het Tertullianus haar huwelik erken, ${ }^{11}$ ) en het Basilius toegegee dat 'n onbevange eksegese van Mattheus 1.25 die huwelik van Maria met Josef handhaaf, ${ }^{12)}$ maar Epiphanius het almal verketter wat hierdie siening gehandhaaf het. ${ }^{13}$ ) Vanaf hierdie oomblik het haar maagdelike betiteling ' $n$ onlosmaaklike predikaat van Maria geword. ${ }^{14)}$

Hierdie sporadiese gedagtewisseling oor Maria het egter meer vorm begin aanneem toe in bepaalde Christelike kringe reeds teen die einde van die tweede eeu - haar lewe met allerlei romantiese besonderhede deurweef is. ${ }^{15}$ ) Ons kry 
naamlik die begin van 'n reeks apokriewe vertellings oor Maria, waarvan die belangrikste hiervan die „Protevangelium Jacobi" en die „De transitu Mariae"16) was. In hierdie apokriewe geskrifte is vrye spel aan die verbeelding gegee. ${ }^{17 \text { ) }}$ Weliswaar het daar stemme van protes teen die apokriewe opgegaan, ${ }^{18}$ ) en het pous Gelasius in $496 \mathrm{n} \mathrm{C}$ alle apokriewe geskrifte verwerp, ${ }^{19)}$ maar selfs hierdie gebod kon nie verhoed dat die legendes in die hart van die volk voortleef nie. $^{20)}$ Nieteenstaande genoemde ontwikkeling stel Zöckler dit egter duidelik dat daar voor die einde van die vierde eeu, geen tendens was ,to promote a regular cultus of the Virgin, or even to address prayers to her". ${ }^{21}$ )

Die eintlike Mariaverering, soos ons dit ken, het op die voorgrond begin tree toe keiser Konstantyn tot die Christendom oorgegaan het en sy voorbeeld deur duisende onderdane nagevolg is. ${ }^{22}$ ) Weens die massale invloei „no little heathenism was brought into the church by those who came into it without any adequate preparation or real change of religous feeling". ${ }^{3}$ ) As die heidene in die Kerk natuurlik suiwer met die Woord van God gekonfronteer was, asook met kerklike praktyke wat voortvloei uit die Woord van God, sou hulle in waaragtige bekering hulle bygelowe afgesweer het. Ongelukkig het dit vir die heidene binne die grense van die Kerk egter nie aan aanknopingspunte ontbreek nie ${ }^{24)}$ - soos byvoorbeeld die martelaarskultus, relikwieëverering, aanroeping van heiliges, verering van engele $e^{25}$ ) - met die gevolg dat baie heidense gebruike onder Christelike vaandel ingesluip het, en ,the type of piety became adapted to the religious condition of those with whom the Church had now to deal."26)

Dit was by hierdie geleentheid dat die Mariolatrie sy debuut in die Christelike kerk gemaak het. Epiphanius ${ }^{27}$ ) meld byvoorbeeld van 'n sekte van dweepsieke vroue wat hulleself priesteresse van Maria noem en wat op feesdae broodkoeke aan haar geoffer het. Hy veroordeel hulle optrede skerp met die vermaning dat Maria in ere gehou moet word, maar dat die Here alleen aanbid moet word. ${ }^{28}$ ) Hierdie terewysing van Epiphanius het egter, wat baie lidmate betref, op dowe ore geval. Die optrede van die vroue was nie 'n geisoleerde geval nie maar simptomaties van die Mariaverering wat in toenemende mate in die kerklike lewe sou voortwoeker. ${ }^{29}$ ) 
Dit was egter in besonder die stryd oor die twee nature van Christus wat die Mariaverering kragtig bevorder het. ${ }^{30}$ ) Vanweë die feit dat Nestorius in sy Christologiese beskouing sterk nadruk op die tweeheid van die nature in Christus gelê het, het hy die benaming van Maria as "moeder van God" vurig bestry ten gunste van die benaming ,,moeder van Christus", ${ }^{11}$ ) Die ekumeniese konsilie te Efese, $431 \mathrm{n} \mathrm{C}$, het die leer van Nestorius verwerp en die benaming ,moeder van God", wat sedert Origenes reeds vir Maria in gebruik was, gesanksioneer. ${ }^{32}$ ) Williams wys tereg daarop dat, wat die konsilie betref, ,any claim to divinity on the part of the mother was not the point at issue,"33) maar ongelukkig kan dit nie van die bevolking gesê word nie. Die bevolking van Efese was buite hulleself van blydskap toe die beslissing bekend geword het. ${ }^{34)}$ Vanaf daardie oomblik toe die inwoners met brandende fakkels en met wierookpanne in prosessie ter ere van Maria beweeg het - op dieselfde patroon as die heidene wat die godin. Diana in hierdie stad gedien het - het die Mariaverering vlam gevat. ${ }^{35}$ )

Die optrede van die Christene van Efese, sowel as van genoemde vroue teen wie Epiphanius opgetree het, ${ }^{36}$ ) bring vanself die brandende vraagstuk na vore of en tot watter mate die heidense godinne tot die Mariaverering bygedra het. Delius is uitgesproke in sy bewering dat, toe die gevaar van die heidendom verby was, die Kerk "also in der Marienverehrung zu deren schneller Förderung Anleihen bei dem Kultus der antiken Göttinnen (konnte) machen."3 7) Hy het die Artemis- en Isiskultusse as prototipes in gedagte. ${ }^{38}$ ) Vir Laing is daar ,indications that the veneration of Diana as a virgin goddess has contributed something to the worship of the Virgin Mary," maar hy waarsku ook teen die ,danger of exaggerating the influence of any one ancient deity in the development of the cult of Mary."39) Kuhn bespeur die invloed van Isis ${ }^{4}$ ) en Schulte die invloed van Athena ${ }^{41}$ ) in die Mariakultus, terwyl James verklaar ,that Mary in her capacity as the Theotokos of Christian traditon gathered round her in due course many of the attributes of the Magna Mater."42) De Klerk ${ }^{43}$ ) en Landwehr ${ }^{4}$ ) soek in die Mariaverering 'n vergoeding vir die aanbidding van die vroulike, soos die heidendom dit in hulle mitologie vergestalt het; maar vir Bulgakov - ofskoon hy toegee dat 'n mens ,a certain obscure 
prescience" van die heidendom kan bespeur - is die verskil tussen die godinne en die Maagd „too evident to warrant any comparison."45)

Om in hierdie doolhof van fluktuerende en kontradikterende gedagtes die regte weg te vind, sal dit nou eers nodig wees om Ambrosius se bydrae tot die Mariaverering in oënskou te neem. Nie dat ons daarmee te kenne wil gee dat Ambrosius die enigste kerkvader was wat 'n bydrae tot die Mariaverering gelewer het nie! Huhn ${ }^{46}$ ) stel dit baie duidelik dat ,zu der Zeit, als Ambrosius seine schriftstellerische Tätigkeit begann, die wichtigsten Mariengeheimnisse: ihre Gottesmutterschaft, ihre Jungfräulichkeit ante partum, in partu und post partum bei kirchlichen Schriftstellern, wenn auch vereinzelt, eine literarische Erörterung gefunden hatten."46) Vanweë die feit, egter dat ,kein Kirchenvater . .... so viel, so warm und innig über Maria geschrieben (hat)," 7) was sy bydrae tot die Mariaverering so uniek, dat hy met reg die „Patron of the veneration of Mary" ${ }^{8}$ ) en die "marianischen Kirchenlehrer"49) genoem word.

Die ontwikkeling van die Mariologiese denkstruktuur by Ambrosius in die tweede helfte van die vierde eeu, vind sy diepste oorsaak in die heroiese stryd wat die kerkvader met die Ariane aangeknoop het. ${ }^{50)}$ Ofskoon die Arianisme algemeen beskou word as ' $n$ trinitariese dwaalleer, was daar tegelykertyd ook sterk elemente van 'n christologiese onregsinnigheid teenwoordig. ${ }^{51)}$ Vanweë sy diepe roepingsbewustheid as biskop het Ambrosius dit as sy sedelike plig beskou om die Godheid van Christus teenoor die Arianisme en die volledige menslike natuur van Christus teenoor die Apollinariste vurig te verdedig, sodat hy die eerste Westerse kerkvader geword het wat „,die Lehre von der Einheit der Person Christi in den zwei vollständigen Naturen stark hervorgekehrt (hat.)"52) Op sy beurt het die Christologiese beskouing van Ambrosius weer 'n sterk bydrae tot die ontwikkeling van sy Mariologiese beskouing gelewer, deurdat hy vir homself rekenskap moes gee van die verhouding tussen Christus en sy moeder en tussen Maria en die mistieke liggaam van Christus, sy kerk. ${ }^{53)}$

Vanweë die feit dat Arius beweer het dat Christus die eerste skepsel van die Vader was, ${ }^{54)}$ was Maria, volgens hierdie beskouing, nie moeder van ' $n$ mensgeworde Persoon van die 
Drie-eenheid nie maar van 'n skepsel, ofskoon Arius vir Maria die titel „Gottesgebärerin gebruik. ${ }^{55}$ ) Teen die dwaalleer van die Ariane, van die Manigeërs (wat vir Christus 'n skynliggaam toebedeel het) $^{66 \text { ) }}$ en van die Apollinariste (wat die waaragtige mensheid van Jesus en sydelings ook sy waaragtige Godheid geloën het), ${ }^{5}$ ) het Ambrosius met klem betoog dat die historiese Christus 'n Goddelike Persoon is maar ook die mensgeworde Seun van God, wat ons só moet begryp dat „ipse igitur utrumque unus." 8 ) "Adversum omnes" stel hy die gemeenskaplike belydenis dat „Christus est Dei filius et sempiternus ex patre et natus ex Maria virgine;" 59 ) en teenoor die Apollinariste, in besonder, dat die twee nature van Christus volmaak is. ${ }^{6}{ }^{0}$ )

As gevolg van die vereniging van die twee nature in Christus, ${ }^{11}$ noem Ambrosius Maria ,mater Domini"6 2) en "mater Dei."6 3) Ofskoon Ambrosius die titel "mater Dei" nie baie in sy geskrifte gebruik nie, ${ }^{64)}$ is die Godmoederskap van Maria vir hom 'n wesentlike vereiste vir die regte geloof in die Godmenslikheid van Jesus Christus. ${ }^{6}$ ) Met sinnebeeldige verklarings van die naam van Maria,${ }^{66}$ ) met 'n beroep op Skriftuurplekke ${ }^{67)}$ en met rasionele beredenering, ${ }^{68}$ ) verdedig Ambrosius met ongekende vuur en ywer die ware moederskap van Maria teen al die dwaalleringe wat die menswording van Christus ontken het. Huhn merk tereg op dat ons dit nie so moet verstaan ,als ob Ambrosius die Marienverehrung hätte begründen wollen, es ging zunächst um Christus;"69) maar as hy verder gaan in sy bewering dat ,in Maria, der Göttesmutter, bekannte und begrüsste er die Gotteswürde Christi, ihres Sohnes, des Erlösers," 70 ) bemerk ons reeds die wesentlike gevaar dat Ambrosius vir Maria 'n plek in die heilgeskiedenis kan toeken wat sy nooit mag beklee nie.

Dat hierdie stelling nie uit die lug gegryp is nie, blyk duidelik uit die Skriftuurlik-onverantwoorde klem wat hy op die maagdelikheid van Maria lê. As Maria, volgens Ambrosius, die moeder van Jesus Christus was, moet ons daaronder nie 'n natuurlike moederskap verstaan nie maar 'n jonkvroulikemoederskap. ${ }^{71}$

Ambrosius bely met klem die leerstelling van die maagdelikheid van Maria ,ante partum". Ons sê met opset,,bely" en nie „ontwikkel” nie, omdat hierdie dogma „had been the 
first Marian privilege to be discussed by Christian writers, and it had become so well established by the fourth century that even most Christological heretics admitted it."72) Met uitsondering van sy himne: „Veni, redemptor gentium,"73) waarin hy die jonkvroulike ontvangeniswonder besing en wat ' $n$ besondere rol in die bekamping van die Nestorianisme gespeel het, ${ }^{74}$ ) het Ambrosius weinig nuuts tot hierdie dogma bygedra. $^{75}$ ) Met sy kenmerkende allegories-mistiese eksegese beroep hy hom op talle plekke in die Heilige Skrif vir die maagdelikheid van Maria ,ante partum." 76 ) As hy egter probeer aantoon dat die huwelik van Josef en Maria net 'n skynhuwelik was - 'n sogenaamde pactio conjugalis ${ }^{77}$ ) - is die gedagtegang van die kerkvader só verwarrend, ${ }^{78}$ ) dat dit vir ons baie duidelik is dat Ambrosius nie die Skrif in onbevange eksegese hier laat spreek nie, maar dat hy besig is om sy vooropgesette teologiese beskouing oor die maagdelikheid van Maria in die Skrif in te dra.

As Ambroius die maagdelikheid van Maria ,ante partum" met gloed verkondig het, so het die maagdelikheid van Maria ,in partu” „in dem Kirchenvater Ambrosius einen begeisterten Verkünder und einen überzeugenden Verteidiger gefunden."79) Sy dogmatiese uitganspunt: ,virgo concepit, virgo peperit . . . Dei Filium"8 0) vorm 'n refrein wat ons telkens in variërende uitdrukkingswyse in sy geskrifte terugvind. ${ }^{81}$ ) Dieselfde gedagtegang naamlik dat die jonkvroulikheid van Maria ongeskonde gebly het ondanks die geboorte van Jesus Christus, word op gloedvolle wyse in sy himnes ,Jam surgit hora tertia" en "Veni, redemptor gentium" besing. ${ }^{82}$ )

As ons 'n rekonstruksie van die gedagtegang van Ambrosius oor hierdie dogma wil gee, ontmoet ons maar weer 'n geforseerde vergeestelikte eksegese. Die bekende woorde van Luk. 2.23: „omne masculinum adaperiens vulvam sanctum Domino vocabitur." - wat baie duidelik die teendeel bewys wat Ambrosius wil bewys - interpreteer hy só asof ,adaperiens vulvam" beteken „om vrugbaar te maak."8 3) Volgens Ambrosius offer 'n vrou haar maagdelikheid op as sy die vreugde van moederskap smaak; en omdat hy dit as geheel en al onvanpas vir Maria beskou, wring hy die verklaring van genoemde teks om te kan beteken: „the all-holy Word by his divine power rendered the womb of his Mother fruitful in such a way that He respected her virginity."84) 
Aanvanklik het Ambrosius dieselfde sobere stilswye oor die geboorte van die Here Jesus as die Heilige Skrif bewaar. ${ }^{85}$ ) Hy was bewus daarvan dat Tertullianus Maria se maagdelikheid tydens die geboorte ontken ${ }^{86}$ ) en dat die apokriewe met hulle verdigsels dit sterk beklemtoon het; ${ }^{87}$ ) maar, "confident of his assertion that Mary was the virgin par excellence, he does not often single out Christ's birth to proclaim the miraculous integrity of His Mother at that moment."8 8 ) Dit was eers toe Jovinianus die bewering gemaak het dat die maagd Maria ná die geboorte van Jesus opgehou het om maagd te wees, ${ }^{89}$ ) dat Ambrosius tot die strydperk toegetree het met die verontwaardige uitroep: „Quanta dementia funestorum latratuum, ut iidem dicerent Christum ex Virgine non potuisse generari, qui asserunt ex muliere, editis humanorum pignorum partubus, virgines permanere! $" 90$ ) en die maagdelikheid van Maria tydens die geboorte openlik verdedig het. ${ }^{11}$

Noudat ons gesien het hoe vurig Ambrosius Maria se maagdelikheid voor en tydens die geboorte van Jesus Christus verdedig het, is dit nie vir ons vreemd dat hy met dieselfde ywer die maagdelikheid van Maria ,post partum" handhaaf nie. Trouens, die benaming "Virgo" wat hy sonder enige kwalifikasie aan Maria toeken, het reeds die geloof in haar voortdurende maagdelikheid geimpliseer. ${ }^{92}$ ) Natuurlik is ook hierdie leerstelling van Ambrosius geen nuwe nie - trouens, hy bou maar net voort op die trasisie. As hy egter die voort durende maagdelikheid van Maria met sy ideaal van jonkvroulikheid in wisselbetrekking bring, word hy ,der erste abendländische Kirchenvater, der das ethische Marienbild eingehend gewürdigt, der die jungfräuliche Gottesmutter als Vorbild namentlich der Jungfräulichkeit hingestellt hat."93)

Om die voortdurende maagdelikheid van Maria te bly handhaaf, moes Ambrosius - onnodig om te sê - met behulp van allegoriese Skrifinterprestasie baie Skriftuurplekke verklaar. As ons met 'n onbevooroordeelde gemoed sy ,De institutione virginis" lees (waarin hy veral teen 'n sekere Bonosus te velde trek wat beweer het dat Maria, ná die geboorte van die Here Jesus, kinders by Josef gehad het); ${ }^{94}$ ) en as ons sien op watter vernuftige wyse hy Skriftuurplekke teen die voortdurende maagdelikheid van Maria verdraai om in sy skema in te pas, is dit baie duidelik dat Ambrosius geen uitlegkunde toepas nie maar inlegkunde pleeg. ${ }^{95}$ ) Dit is dan ook 
geen wonder dat die kerkvader tot sulke verregaande konklusies kom, wat sulke verreikende gevolge gehad het nie, soos byvoorbeeld: dat Christus dit van Maria verwag het om haar as hemelse paleis onbevlek te bewaar; ${ }^{96)}$ dat die geboorte van Christus die grootste aansporing tot maagdelikheid is; ${ }^{9}$ ) dat Maria die ,,aula coelestium sacramentorum" die bewaarplek van goddelike misterieë is; ${ }^{98}$ ) dat Maria nie net liggaamlike maagdelikheid nie, maar ook geestelike maagdelikheid besit;99) dat Maria haar maagdelikheid nie slegs bewaar nie maar uitdeel en sodoende die kanaal word waardeur die genade van maagdelike integriteit aan andere oorgedra word. ${ }^{100}$ )

Asof Ambrosius die plek van Maria in die heilsgeskiedenis nog nie duidelik genoeg bepaal het nie, gaan hy voort om op voetspoor van die kerkvaders ${ }^{101)}$ - Maria in teenstelling met Eva te bring. Aanvanklik stel hy slegs: „per os mulieris mors ante processerat, per os mulieris vita reparatur,"102) maar spoedig daarna kontrasteer hy die „mulier" Eva met die "virgo Maria."103) Wanneer hy dan nog later beweer dat "per virum et mulierem caro eiecta de paradiso per virginem juncta est deo,"104) „erfährt die Jungfräulichkeit ein besonderes Lob, eine Höherstellung über die Ehe, wegen ihres Verdienstes um die ganze Menschheit; aber es ist die ,virginitas' Mariens, die ,virgo' Maria, die den Fluch wieder gut gemacht hat."105)

As ons reken dat die vergelyking Eva - Maria uitgeput is, begaan ons 'n groot fout. Net soos hy Maria as die tweede, nuwe, Eva teken, teken hy die Kerk ook as die tweede Eva, weereens op voetspoort van die kerkvaders. ${ }^{106}$ ) Ook as Ambrosius die Kerk as Bruid van Christus voorstel, ${ }^{107)}$ en hoe paradoksaal dit ook mag klink - die Kerk tegelykertyd as „immaculata virgo"109) en "mater viventium"109) bestempel, volg hy nog in die spore van die kerklike oorlewering. ${ }^{1}{ }^{0}$ )

Kom Ambrosius vervolgens met sy vergelykings Maria - Eva en Kerk - Eva tot die slotsom dat „Maria est typus ecclesiae,"1 11) word hy die eerste kerkvader wat hierdie uitdrukking gebruik. ${ }^{112)}$ Vanweë die gedronge uitdrukking is dit moeilik om sy gedagtegang te bepaal. Nadat Huhn hierdie uitdrukking tegnies ontleed het, ${ }^{13}$ ) kom hy tot die slotsom dat „Maria und die Kirche werden geleichgesetzt" - in dié sin 
dat „,nicht nur is Maria ein Bild der Kirche, auch die Kirche ist ein Bild Mariens."114) Getrou aan sy paradoksale bewering van die Kerk as maagd en moeder, besing hy Maria as tipe van die Kerk in haar jonkvroulikheid, ${ }^{116}$ ) maar ook as geestelike moeder van al die gelowiges. ${ }^{116}$

Die feit dat Maria, as moeder van die Here Jesus, en as tipe van die Kerk, op so 'n innige wyse in die werk van die Here betrek is, laat by Ambrosius die vraag ontstaan of Maria ook ' $n$ aandeel het in die verlossingswerk van Jesus Christus. ${ }^{117}$ ) As hy sy geliefde tafereel van Maria by die kruis teken, klink dit telkens soos 'n refrein: ,,putabat se aliquid publico addituram muneri"1 18) en: „praestolabatur si forte etiam sua morte publico muneri aliquid adderetur."119) Herhaaldelik beantwoord: Ambrosius hierdie vraag: „Sed Jesus non egebat adjutore ad redemptionem omnium"1 20) en: „Unus est, qui secundum non habet; quia unicus solus sine peccato, solus sine adjutorio, qui ait: Respexi, et non erat adjutor (Esai 63,5)"121 ) Hierdie kategoriese antwoord van die kerkvader moet ons egter nie tot die slotsom laat geraak dat hy Maria geheel en al uitskakel nie! Inteendeel. „Es war dem Kirchenvater Ambrosius klar, dass Maria, die Mutter des Erlösser, mit Christus im Erlösungswerk vereinigt ist."1 22) Hoe innig Ambrosius Maria inderdaad inskakel in die verlossingswerk van Christus, blyk uit sy stelling dat die toestemming van Maria eers die vleeswording van Chrustis moontlik gemaak het; ${ }^{133}$ ) en dat Maria as middelares 'n werklike invloed in die heilsekonomie uitoefen in soverre as wat sy „redemptionem genti genuit humanae."1 24 )

As ons tot dusver sterk polemiese en tipologiese trekke in die Mariabeeld by Ambrosius ontdek het, moet ons tog nie dink dat dit vir Ambrosius bloot 'n dogmatiese aangeleentheid was nie. Inteendeel. As man wat op die praktyk gerig was as entoesiastiese bewonderaar en verkondiger van die maagdelike staat, 125 ) wou hy by uitstek 'n etiese Mariabeeld daarstel wat navolging verdien. ${ }^{126)}$ Hierdeur het hy dan ook, "der erste kirchliche Schrifsteller des Abendlandes" geword wat ,ein verhältnismässig vollendetes Bild des sittlichgeistigen Wesens der Gottesmutter gezeichnet hat."1 27 )

In sy begeerte om Maria as model-maagd vir die jonkvroue van sy tyd voor te hou, ${ }^{128}$ ) besing hy die deugde van Maria 
op so 'n entoesiastiese wyse soos nog geen kerkvader voor of na hom nie. ${ }^{129)}$ "Quantae in una virgine species virtutum emicant"130) roep hy in vervoering uit. Nie alleenlik beoefen sy al die deugde nie maar onderrig dit ook ${ }^{131}$ ) Haar nederigheid ${ }^{132)}$ stilswye, ${ }^{133}$ ) afsondering ${ }^{134}$ ) ingetoënheid, ${ }^{135}$ ) toewyding in die lees van die skrif, ${ }^{136}$ ) eerbied vir ander, ${ }^{137}$ ) haar ywer1 38) en in besonder haar ,fides"139) en ,devotio", $(40)$ is maar enkele van die uitstaande deugde wat ons hier wil noem. ${ }^{141)}$

Om so 'n Mariabeeld op te tower - onnodig om te sê - moes Ambrosius aan haar eienskappe toeken wat haar ver bokant 'n gewone mens stel.' Asof hy die nog nie reeds genoegsaam gedoen het in haar tipologiese betekenis nie, teken hy haar as hoof van die ,"chorus virginum" in die hemel; ${ }^{142)}$ word hy die eerste kerkvader „der sich eingehend und unzweideutig über die Freiheit Mariens von aller persönlichen Sünde ausspricht; ${ }^{143)}$ en ontvang hy ook die toekenning dat hy die eerste kerkvader is wat haar die predikaat „sancta" toegevoeg het. ${ }^{144)}$

Noudat ons Ambrosius se bydrae tot die Maria-verering in oënskou geneem het, kom die brandende vraag na vore waarom Ambrosius só vasgeklem het aan die maagdelikheid van Maria en haar só verheerlik het, dat hy die „marianischen Kirchenlehrer"1 46) genoem word.

Uit die oorsig wat ons van die ontwikkeling van die Mariologiese denkstruktuur by Ambrosius gebied het, is dit - eerstens - baie duidelik dat die stryd, wat die kerkvader o a met die Ariane, Jovinianus en Bonosus moes voer, hom genoodsaak het om oor die plek van Maria in die heilsgeskiedenis te besin ${ }^{146)}$ As Ambrosius die Skrif alleen in 'n on bevange eksegese laat spreek het, sou sy teologiese besinning oor Maria Skriftuurlik-suiwer gewees het, maar nou het hy dit nie gedoen nie! Vanweë sy allegoriese Skrifverklaring, ${ }^{147)}$ waarin hy sterk deur Origens beinvloed is; ${ }^{148}$ ) en waardeur ,the letter of the sacred text, if not altogether set aside, was given less that its due weight; and the Bible was forced to say whatever the exegete decided that it ought, in the interest of the orthodox faith, to say;" 49) het Ambrosius sekere leerstellings oor Maria geformuleer wat sekerlik die toets van die tradisie kon deurstaan, maar nie die toets van Gods Woord nie. As ons daarby nog in gedagte hou dat Am- 
brosius 'n sterk voorliefde vir die ,virginitas" gehad en Maria as voorbeeld van maagdelikheid voorgehou het, ${ }^{150}$ ) kan ons begryp hoe maklik dit vir hom was om vooropgesette gedagtes in die Skrif, met behulp van die allegoriese metode, in te dra.

Die invloed van die kant van die heidense godinnedom was tweedens - nog 'n groot rede waarom die Mariaverering so toegeneem het. Daar het inderdaad 'n groot waarheid in die beskuldiging van die heidene gesteek dat die Christene Maria as godin vereer het, natuurlik na analogie van die verering van die heidense moedergodinne. ${ }^{161)}$ Hierdie beskuldiging is ongetwyfeld heftig deur die Christene ontken. Nêrens lees ons ook in die geskrifte van Ambrosius van enige ooreenstemming tussen Maria en enige moedergodin nie. Trouens, uit die feit dat hy die titel "mater Dei" so spaarsaam gebruik, ${ }^{152}$ ) lei Huhm daaruit af „das die Christen gerade in der zweiten Hälfte des vierten Jahrhunderts eine starke Auseinandersetzung mit dem Kult der Kybele, der, Göttermutter', durchzukämpfen hatten" en dat Ambrosius daarom doelbewus enige skyn van ooreenkoms wil vermy. ${ }^{153)}$

Ondanks hierdie ontkenning van enige doelbewuste ooreenkoms, wil ons tog die bewering maak dat baie Christene in hulle Mariaverering deur die heidense moedergodinne-verering sterk beinvloed is. Ook wil ons die bewering maak dat Ambrosius, hoewel nie bewustelik nie, tog wel onbewus, deur die Klassieke kultuurpatroon in hierdie verband beinvloed is. As ons byvoorbeeld gedagtig is aan die Artemis- en Isiskultusse; $^{154}$ ) aan die maagdelike godin Diana; ${ }^{155}$ ) aan die moedergodin Cybele; ${ }^{156)}$ aan die ,,weibliche Himmelsgottheit und Genossin Juno"157) en aan „Vesta mater," „das einzige weibliche Mitglied des Kreises der obersten Götter der alten Rangordnung;" (58) dan is die ooreenstemming tussen sekere aspekte van hierdie kultusse en die Mariakultus só opvallend, dat ons slegs een verklaring daarvoor kan vind naamlik dat die Christene - en in besonder ook Ambrosius - deur genoemde beinvloed is. Gedagtig aan die waarskuwing van Laing teen die gevaar ,of exaggerating the influence of any one ancient deity in the development of the cult of Mary,"159) sal ons met hierdie bewering volstaan dat Ambrosius - hetsy dan ook onbewus - 'n algemene beinvloeding van die moedergodinne-kultus ondergaan het. 
Wanneer ons nou, ten slotte, sy teologiese besinning oor Maria, sy allegoriese Skrifinterpretasie en die invloed, wat hy van die Klassieke ondergaan het, met mekaar verbind; en wanneer ons die opmerking van Huhn in gedagte hou dat geen kerkvader "so viel, so warm und innig"160) oor Maria geskryf het nie, kan ons begryp dat Ambrosius - meer as enige kerkvader vooór of ná hom - vir die trait d'union tussen die Mariabeeld en die heidense godinnedom verantwoordelik was. Sonder dat hy dit ooit kon of wou voorsien, was sy dogmatiese uitsprake oor Maria verantwoordelik vir die kumulatiewe eer wat Maria van Christene ontvang het, wat nooit ten volle die kultus van die Grieks-Romeinse godinne kon afsweer nie. Ondanks die feit dat ons geen kultiese verering van Maria by Ambrosius vind nie (ofskoon Huhn ${ }^{161}$ ) van mening is "dass Ambrosius auch selbst Maria verehrt hat, wenn wir auch in seinen Schriften kein Zeugnis seiner Privatverehrung besitzen)": en ondanks die feit dat Ambrosius die oormatige eer vir Maria probeer teëwerk het met sy bewering dat „Maria erat templum Dei, non Deus templi. Et ideo ille solus adorandus, qui operabatur in templo,"162) het sy begeesterde uitroep: „Quis non honorabit tot virginum matrem? quis non venerabitur aulam pudoris?"163) die Mariakultus sterk bevorder. Coulton, wat op die funeste gevolge van die Mariaverering in die Middeleeue wys, ${ }^{164)}$ beweer tereg dat die „official religion" Maria altyd met reserwe vereer het, maar dat dit die "popular mind" was wat tot sulke buitensporighede aanleiding gegee het. ${ }^{165}$ )

Ambrosius se Marialeer het grootliks tot hierdie uitwasse van die „popular mind" bygedra. As ons daaraan dink dat pous Pius $\mathrm{X}$ die geestelike moederskap van Maria op grond van Ambrosius se bewering: ,ad omnium salutem eum concepit et peperit" geproklameer het; ${ }^{166)}$ as ons o a aan sy invloed op pous Leo XIII via Thomas van Aquino, ${ }^{167)}$ op Augustinus ne pous Leo die Grote ${ }^{168}$ ) dink, kan ons met reg die bewering maak dat Ambrosius, meer as enige ander kerkvader, tot die bestendiging en uitbouing van die Mariaverering in die Roomse Kerk bygedra het. In hierdie verband was hy by uitnemendheid 'n oorgangsfiguur tussen die Klassieke en Christelike kultuurpatroon.

C J MALAN Pretoria 


\section{VERWYSING}

1. Cf Matth $1.16-25 ; 2 ; 12.46-50$; Markus 3.31-35; Luk 1.26-56; 2.1-51; 8.19-21; Joh 2.1-5; 2.12; 19.25-27; Hand 1.13-15;

2. Luk 1.28

3. Kaften, e a GRUNDFRAGEN EINER EINIGUNG DER KICHE CHRISTI, p 69 - aangehaal deur Janssens, A, DE HEILIGE maagd en moeder Gods Maria.

4. Lodder, W, MARIA, DE MOEDER DES HEREN, p 181: ,Men eerde Maria als de moeder des Heren, zonder haar evenwel in't gebed aan te roepen of om haar voorspraak te vragen." Duruy, $\mathrm{V}$, HISTORY OF ROME AND THE ROMAN PEOPLE, p 177: "The Virgin, who occupies so great a place in the Catholicism of modern times, had very little in the early ages. Mention is made of her with respect, but no worhsip is rendered to her"; van Dijk, Mariaverering (IN: Chr Enc, 2de druk, 4:585).

5. Duruy V op cit, p 177.

6. Cf Cooper, Mary (IN: Enc of religion and ethics, 8:475)

7. Justinuns, Dialoog 100 - volgens Quasten J. PATROLOGY, ook 298: „Justin was the first to show the parallelism between Eve and Mary, as Paul had done between Adam and Christ."

8. Irenaeus, Adv Haer, 3.22.4 - volgens Quasten, op cit, 1.297,298.

9. Zöckler, Mary, mother of Jesus Christ (IN: The new Schaff-Herzog enc. of religious knowledge, $7: 220-1$ ).

10. Ibid.

11. Tertullianus, De monogamia, 8.2.

12. Basilius, Homilia in Christi generationem, 5 - volgens Zöckler, op cit, p 220-1.

13. Epiphanius, Haer 78 - volgens Zöckler, op cit, p 220-1.

14. Zöckler, op cit, p 220-1.

15. Lodder, op cit, p 181.

16. Cf Gibson, Mary, the Virgin (IN: A Protestant dictionary, 391): „The real source of Mariolatry is to be found in apocryphal writings." Zöckler, op cit, p 220: „There developing views took shape as legends in a long series of Apocryphal narratives." 17. Cf Lodder, op cit, p 183.

18. Volgens Janssens, op cit, p 45 het die Latynse leraars die apokriewe as waardeloos beskou. Cf p 105: „Nooit echtehebben de Kerkvaderen of de erkende theologen de apocrypha gebruikt als gezaghebbende, kerkelijke overleveringen."

19. Lodder, op cit, p 182: Cooper, op cit, 8:475,6

20. Lodder, op cit, p 182

21. Zöckler, op cit, 7:220; Impeta, MARIAVEREERING (in , Chr Enc, 1ste druk, 4:77)

22. Cf Lodder, op cit, p 182; Zöckler, op cit, p 7:220; Cooper, op cit, 8:475,6: "With the conversion of Constantine Christianity became fashionable, and, as Newman puts it, the spirit of the world was poured into the Church." (THE ARIANS OF THE FOURTH CENTURY, Londen, 1876, p 258).

23. Ayer J C, A SOURCE BOOK FOR ANCIENT CHURCH HISTORY, p 397. 
24. Cf Cramer J A, GESCHIEDENIS VAN DIE EERSTE ZES EEUWEN DER CHR KERK, p 210.

25. Vir meer besonderhede cf Cramer, op p 207-214.

26. Ayer, op cit, p 396,

27. Epiphanius, Haer 79 - volgens Zöckler, op cit, 7:220. Cf Cooper, op cit, 8:475-6; Lodder, op cit, p 180-3.

28. Cf Epiphanius, Haer 79.9 - volgens Cooper op cit, 8:475-6.

29. Cf Cramer, op cit, p 212, Lodder, op cit, p 184-5.

30. Lodder, op cit, p 183; Zöckler, op cit, 7:220.

31. Cf Zöckler, op cit, 7:220; Polman, Nestorius. (IN: Chr Enc 2de druk, 5:190); Lodder, op cit, p 183.

32. Williams $R$ R, A GUIDE TO THE TEACHINGS OF THE EARLY CHURCH FATHERS, p 202; Lodder, op cit, p 183.

33. Ibid.

34. Lodder, op cit, $p 183$.

35. Laing G J, SUR VIVALS OF ROMAN RELIGION, p 93, 94; Lodder, op cit, $p 183$.

36. Cf Verw 27 en 28.

37; Delius W, GESCHICHT DER MARIENVEREHRUNG, p 33.

38. Id p 34: "Neben dem Artemiskult ist fir die Mariensverehrung der Kult der ägyptischen Isis Fördernd gewesen."

39. Laing, op cit, p 93.

40. Kuhn A B, SHADOW OF THE THIRD CENTURY, p 155.

41. Schulte F W C, De vorming tot staatskerk (IN: Gesch der Kerk) 1.140).

42. James E O, CHRISTIAN MYTH AND RITUAL, p 226, 227.

43. De Klerk B J, DIE ROOMSE GEVAAR, $p 16$.

44. Landwehr J H, BEKNOPT LEERBOEK DER KERKGESCHIEDENIS, p 76.

45. Bulgakov S. THE ORTHODOX CHRUCH, p 140.

46. Huhn J, DAS GEHEIMNIS DER JUNGFRAU-MUTTER MARIA NACH DEM KIRCHENVATER AMBROSIUS, p 9: cf. Agius A, The blessed virgin in Origen and st Ambrose, DOWNSLDE REVIEW; 5:190, p 126 .

47. Ibid.

48. Altaner B, PATROLOGY (vertaal deur Graef, Hilda C) p 455.

49. Sträter $P$, red KATHOLISCHE MARIENKUNDE, 1:164. cf McGuire M R P, AMBROSE (IN: Catholic Enc, 1:375); Agius); op cit, p 126: „St Augustine ... has been credited with the honour of being Our Lady's chief champion anyhow in the West. He was not, however, the pioneer in this field. His inspiration in thought, and often in word, is derived from St. Ambrose." Neumann $\mathbf{C ~ W}$, The virgin Mary in the works of st Ambrose, $p$ 3 .... „Ambrose, who was one of the earliest to depict Mary as the Virgin of virgins, and the first whom Christian literature shows doing so with such enthusiasm."

50. Cf Huhn, op cit, p 9.

51. Ibid: „Auch Athanasius hat den Arianismus hauptsächlich als eine christoloriache Häresle behandelt."

52. Id, p 10. 
53. Id, p 11 Cf Harnack, DOGMENGESCH 2:448: „Dadurch, dass das Inkarnationsdogma das Zentraldogma wurde, erhielt Maria ihre wichtigste, geradezu dogmatische Bedeutung" (aangehaal deur Huhn), p 11.

64. Vir 'n uiteensetting van die leer van Arius cf Schulte, op cit, $p$ 117-23.

55. Cf Loofs, NESTORIANA. Halle 1905 S273, volgens Huhn, op cit, p 13.

56. Huhn, op cit. p 13.

57. Van Unnik. Apollinaris (IN: Chr enc, 2de druk, 1:260-1).

58. Ambrosius, In ps 61,5 .

59. Id, De incarnationis dominicae sacramento 5.35 .

60. Id, De excessu fratris sui Satyri 1.12

61. "In dem emphatischen Betonang der individuellen Einheit in Christus bei der Zweiheit der Naturen geht der Mailänder Kirchenvater keine neuen Wege in der Lehre, der grosse Alexandriner Origenes, dessen Werke der Bischof Ambrosius eifrig studiert und benutzt hat, ist ihm darin Vorgänger und Vorbild. Origenes ist auch der erste Schriftsteller, der aus der hypostatischen Union der beiden Naturen in Christus die logische Folgerung zieht, die communicatio idiomatum" - Huhn, op cit, p 15.

62. Ambrosius, De off $\min 1.18 .69$.

63. Id, De virginibus 2.21.

64. Volgens cit, p 16 is die titel "mater Dei" in kerklike Huhn, op kringe' nie „da der Kult der Göttermutter Kybele noch eine Gefahr war und es leicht den Anschein erwecken konnte, als hätten die Christen Titel und Würde der Kybele auf Maria Ubertragen."

65. Cf Huhn, op cit, p 17.

66. Ambrosius. De institutione virginis 5.33: „Unde et speciale Maria Domini hoc nomen invenit, quod significat: Deus ex genere meo" 5:34: „Dictae sunt et ante Mariae multae: nam et Maria soror Aaron dicta fuit (Exod 15.20, 23); sed illa Maria amaritudo maris vocabatur."; Neumann, op cit, p 53 noem dit ,strange etymologies of the name Mary"; en van Wijk P Vinc, De naam Maria, p 9 verklaar: „etymologisch zij deze verklaringen van de grooten Bisschop van Milaan volstrekt onhoudbaar."

67. Expos ev Luc 2.56: immaculatum semen inviolabili utero spiritus sanctus infudit"; Lukas 1:35; cf De incarn Dom sacr 6:53.

68. $\mathrm{Da}$ sich mit dieser menslichen Natur der Sohn Gottes in hypostatischer Union verbunden hat, ist Maria Mutter des Sohnes Gottes" - Huhn, op cit, p 33.

69. Huhn, op cit, p 17.

70. Ibid.

71. Cf Ambrosius, De poenitentia 3.13 ; , Non enim sicut omnis homo est, ex virili erat et feminea permixtione generatus: sed natus de Spiritu sancto et de Virgine (Matth. 1'18), immaculatum corpus susceperat." Vgl ook Huhn, op cit, p 37: „der Gottmench Jesus Christus verdankt seinem irdischen Ursprung einer jungfräulichen Mutter." 
72. Nuumann $C$ W, THE VIRGIN MARY IN THE WORKS OF SAINT AMBROSE, p 67.

73. Cf Migne PL 16.1410,11.

74. Huhn, op ct, p 75: „In der Bekämpfung des Nestorianismus ... spielten diese Verse unseres Kirchenvaters eine besondere Rolle."

75. Neumann, op cit, $\mathrm{p} 67$.

76. Luk 1.16-38; Joh 1.13; Matth 1.20 Jes 7.14; Joh 19,26, 27; cf Neumann, op cit, p 69-73 vir bespreking van die tekste.

77. Ambrosius, De institutione virginis, 6.41.

78. Cf vir die verwarrende gedagtegang Neumann, op cit, p 85-100.

79. Huhn, op cit, p 112.

80. Ambrosius, De virginitate 65.

81. Cf Ambrosius, De obitu Theodosii oratio 44: „Vicit te Maria, quae genuit triumphatorem, quae sine imminutione virginitatis edidit eum qui crucifixus vinceret te."; De mysteriis 53.

82. Cf Migne PL 16.1410 en 11 .

83. Vir detailbespreking cf Neumann, op cit, p 113-118.

84. Neumann, op cit, p 135

85. Id, p 105,138

86. Cf Tertullianus, De carne Christi 23.

87. Neumann, op cit, p 106.

88. Id, p 105

89. Cf Ambrosius, Ep 42.4.

90. Ibid.

91. Vir sy argumentasie ef Neumann, op cit, p 164-177.

92. Neumann, op cit, p 183.

93. Huhn, op cit, p 210.

94. Bonosus het o a aangevoer dat Maria "mulier" genoem word (Mt 1.25); dat "antequam convenirent"' (Mt 1.18) beteken dat huweliksgemeenskap gevolg het, dat "non cognovit eam donec peperit" dieselfde beteken (Mt 1.25); dat die "fratres Domini" (Mt 12.46) ander kinders van Maria beteken - cf Neumann, op p 236.

95. Vir sy eksegese cf Neumann, op cit, p 237-257.

96. Ambrosius, De institutione virginis $6.44 ;,$,An vero Dominus Jesus eam sibi matrem eligeret, quae virili semine aulam posset incestare coelestem, quasi eam cui impossibile esset virginalis pudoris servare custodiam"

97. Id, 17.104.

98. Id, 7.50 .

99. Cf Neumann, op cit, p 196.

100. Bv aan Johannes die Doper en Johannes die Evangelis. Cf de inst virginis 7.50.

101. Cf verw. 7 en 8

102. Expos ev luc 20.156; cf Huhn, op cit, p 130.

103. Ep 42.3: „per mulierem cura successit, per virginem salus evenit."

104. Ep 63.33.

105. Huhn, op cit, p 130.

106. Id, 134 .

107. In ps $118,1,4$; De fide 3.71 . 
108. Expos ev Luc 4.50 ef Huhn, op cit, p 140.

109. Expos ev Luc 2,96 - cf Huhn, op cit, p 141.

110. Cf. Huhn, op cit, o 139.

111. Expos ev Luc 2.7.

112. Huhn, op cit, p 146:, So ist unser Kirchenvater auch der erste Kirchenschriftsteller, der für das Verhältnis Maria-Kirche, für das, was die früheren Vảter darunter verstanden, den Ausdruck prägte."

113. Cf p 144-151.

114. Id, p 151.

115. Ambrosius, De inst virg 14.87 e v.

116. Cf De inst virg, 98. Op grond van Ambrosius se bewering ,ad omnium salutem eum concepit et peperit", het pous Pius X die geestelike moederskap van Maria geproklameer - Pius X, Ad diem illum, 2 Feb 1904 (Civilta Cattolica 1904,1,521), volgens G Smith DIE STELLUNG MARIENS IM ERLOSUNGSWERKE CHRISTL, übers von Erasmi, Padeborn 1907 S 165 - aangehaal deur Huhn, op cit, p 162.

117. Volgens Huhn, op cit, p 169 word hierdie vraag ,, zum erstenmal in der christlichen Literatur bewusst gestellt."

118. Ep 63.110

119. De inst virg. 7.49

120. Ep 63.110; cf Expos ev Luc 10132

121. De inst virg 1068.

122. Huhn, op cit, p 180

123. Expos fidei: „Jesum Christum Filium Dei . . . dignatus est, post sanctae Virginis assensum..."

124. De mysteriis 13. Cf Ep 63.33.

125. Cf Ambrosius. De viduis 12.72; de virg 1.7.35.

126. In Ep 63.111 word sy as voorbeeld vir alle moeders gestel.

127. Huhn, op cit, p 191.

128. Cf Neumann, op cit, p 37,38 .

129. Veral in die tweede boek kan sy „De virginibus,"

130. Ambrosius, De virg 2.2.15.

131. Id, 2.29 .

132. Id, 2.2.7: "corde humilis".

133. Ibid: „Ioquendi parcior”, ,verecunda sermone”.

134. Id, 2.2.9.; Ep 5.16.

135. Id, $2,2.7$.

136. Ibid.,

137. Ibid: „nullum laedere."

138. Ibid: "intenta operi".

139. Id, 2.2.15: ,vexillum fidei."

140. Ibid ,devotionis obsequium."

141. Vir verdere deugde of de virginibus 2 ; de off $\min 1.60 .258,1.18$. 69.

142. Cf vir 'n bespreking van die „chorus virginum" Neumann, op cit, p 51-64.

143. Dudden F H, THE LIFE AND TIMES OF ST AMBROSE, p 601 is van mening dat Ambrosius, , did not maintain (as Augustine 
afterwards was disposed to maintain) that Mary was without actual sin". As ons egter die volgende uitsprake in ag neem: „Non de terra utique, sed de coelo vas sibi hoc per quod descenderet Christus elegit, et sacravit templum pudoris" (De inst virg 5.33); "Suscipe me in carne, quae in Adam lapsa est. Suscipe me non ex Sarra, sed ex Maria, ut incorrupta sit virgo, sed virgo per gratiam ab omni integra labe peccati (Expos in Ps 118,22.30) - kan ons met hierdie uitspraak van Huhn saamstem.

144. Ambrosius, De inst virg 103: „sancta Maria."

145. Cf verw 49.

146. Cf verw $54-60,89,90,94$.

147. Cf Dudden, op cit, p 457-459; Thornton R, St Ambrose: his life, times and teaching, $p 142$ e.v.

148. Dudden, op cit, $p 457$; Thornton, op cit, $p 142$.

149. Dudden, op cit, p 459.

150. Cf Hughes P, A HISTORY OF THE CHURCH, 1.142: „St Ambrose breaks entirely new ground when he suggests Our Lady as the type and model of the consecrated virgin."

151. Cf Huhn, op cit, p 272.

152. Ambrosius gebruik die titel slegs tweekeer in sy geskrifte nl De virginibus 2.2.7 en Exam 5.20. 65.

153. Huhn, op cit. p 272.

154. Delius W. GESCHICHTE DER MARIENVEREHRUNG, p 33 sien die Artemis- en Isiskultusse as prototipes van die Mariakultus.

155. Laing G J, SURVIVALS OF ROMAN RELIGION, p93, meen dat ,the veneration of Diana as a virgin goddess has contributed something to the worhsip of the Virgin Mary."

156. Cf Cary M. A HISTORY OF ROME p. 273.

157. Wissowa G, RELIGION UND KULTUS DER ROMER, p 113.

158. Id. $p 141$.

159. Laing, op cit, p 93

160. Huhn, op cit, p 9.

161. Id, p 271.

162. Ambrosius, De Spiritu Sancto 3,80 .

163. Ambrosius, Exhortatio virginitatis 27.

164. Cf Coulton G G, FIVE CENTURIES OF RELIGION,

165. Id, p 139.

166. Cf verwysing 116.

167. Cf Huhn, op cit, p 180.

168. In 'n aparte hoofstuk: "Das Weiterwirken der Marienlehre des heiligen Ambrosius," wys Huhn, op cit, p 271-286, op die invloed wat Ambrosius se Mariabeskouing op Augustinus en pous Leo die Grote gehad het. 